\title{
Some Remarks on The History of Political Theory in Antiquity
}

\author{
Laurens Winkel
}

\author{
Erasmus University Rotterdam \\ Contacte-mail:winkel@law.eur.nl
}

\begin{abstract}
:
With the help of some texts of Greek philosophers the ambivalent history of natural law philosophy is illustrated with its consequences for the rising notion of political theory and international law. Universalism and Stoic philosophy form the intellectual background for the rising Roman empire. Special attention is paid to the history of the textual transmission of some important philosophical texts, an aspect which is very often neglected.
\end{abstract}

Keywords: natural law; Plato; Aristotle; stoicism; universalist forms of philosophy; textual transmission

DOI: $10.14712 / 2464689 X .2021 .29$

It is a commonplace that Greek moral philosophy before Socrates consists in a form of natural law philosophy, where one of the main questions is essentially an epistemological one: what does nature teach us? This question is for example visible in treatises on the

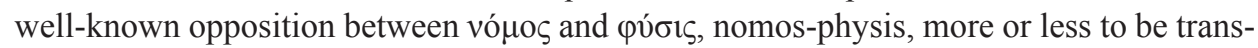
lated as: human custom-nature, and it plays a role in nearly every aspect of the philosophy at that time, the Ionian philosophy of nature. ${ }^{1}$ This also applies to the part of philosophy which we are accustomed to call political philosophy nowadays.

A more developed form of political philosophy can be found in the philosophy of Plato (427-347), e.g., in his dialogue Gorgias where once again the old opposition between nomos and physis is elaborated:

1 HEINIMANN, F. Nomos und Physis. Basel, 1945. Repr. Darmstadt: Wissenschaftliche Buchgesellschaft, 1978, p. 13ff, 42ff. 
Plato, Gorgias 483 b-c

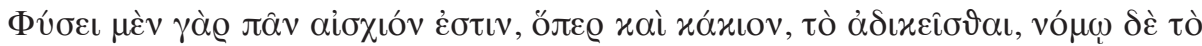

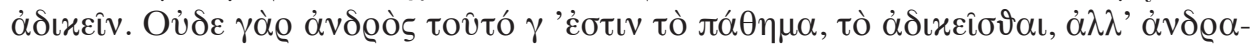

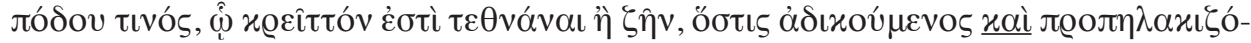

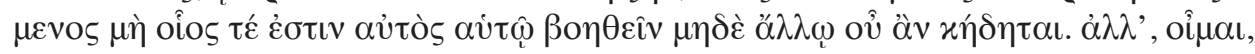

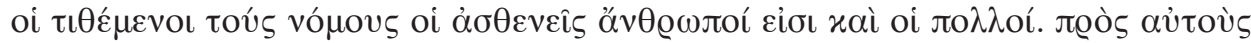

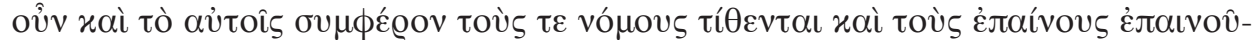

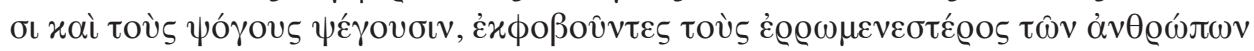

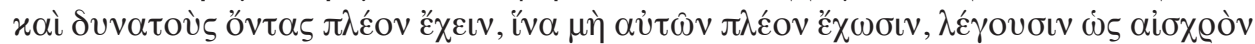

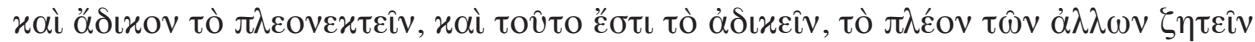

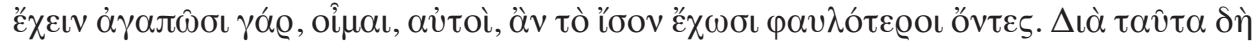

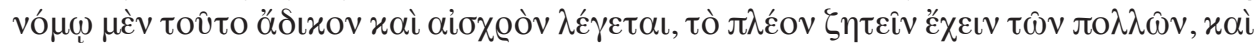

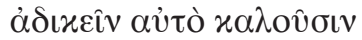

"For by nature ('physis') everything that is worse is more shameful, suffering wrong for instance, but by convention ('nomos') it is more shameful to do it. For to suffer wrong is not even fit for a man, but only for a slave, for whom it is better to be dead than alive, since when wronged and outraged he is unable to help himself or any other for whom he cares. But in my opinion those who framed the laws are the weaker folk, the majority. And accordingly they frame the laws for themselves and their own advantage, and so too with their approval and censure, and to prevent the stronger who are able to overreach them from gaining the advantage over them, they frighten them by saying that to overreach others is shameful and evil, and injustice consists in seeking the advantage over others. For they are satisfied, I suppose, if being inferior they enjoy equality of status. That is the reason why seeking an advantage over the many is by convention ('nomos') said to be wrong and shameful, and they call it injustice. But in my view nature ('physis') herself makes it plain that it is right for the better to have the advantage over the worse, the more able over the less." 2

In this fragment of the dialogue Gorgias ( $\pm 480-375 \mathrm{BC})$ is speaking, being one of the so-called sophists and in his days a strong opponent to Athenian democracy. ${ }^{3}$ Plato deals with him in this dialogue of the same name and explains his views on political organization. Democracy is framed here by Gorgias as a conspiracy of the majority of weak people against the aristocratic and better minority. However, this philosophical discussion must not distract from the fact that the prevailing form of government in Athens was most of the time a democracy until the reign of Alexander the Great. ${ }^{4}$

The topic "what does nature teach us?" also appears occasionally in Aristotle in the 4th century BC. The Swiss theologian Felix Flückiger has dealt extensively with this topic in his unfortunately unfinished book on the history of natural law philosophy. ${ }^{5}$ Natural law is present in Aristotle (384-322) in several ways, for example in his doctrine that man is from

2 Translation: The Collected Dialogues of Plato. HAMILTON, E. - CAIRNS, H. (eds.). Translated by COOPER, L. Princeton: Princeton University Press, 1978.

3 See on Gorgias: GUTHRIE, W. K. C. A History of Greek Philosophy. III. Cambridge: Cambridge University Press, 1962, pp. 269-274.

4 See e.g., FINLEY, M. Democracy ancient and modern. London: Chatto \& Windus, 1973, p. 42ff.

5 Only the first part was eventually published: FLÜCKIGER, F. Geschichte des Naturrechts. I. ZollikonZürich: Evangelischer Verlag, 1954, p. 163ff. 


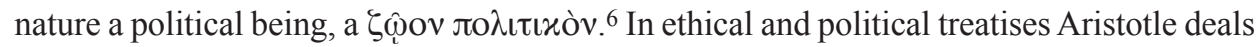
with this topic, for he is not only the author of the Nicomachean Ethics, but of the Politics as well. The Politics is in many aspects a continuation of the Nicomachean Ethics, maybe it even was originally one treatise or - even more probable - one long series of lectures. ${ }^{7}$ Hence the references in the Politics to the most probably somewhat earlier ethical treatise. ${ }^{8}$ The textual tradition of the Politics is partly obscure and the reconstruction of the text has not always been successful. This is the reason why we find quite some anacoluthon phrases for which it is difficult to find the exact context and meaning. An important example of such a phrase is dealt with below. ${ }^{9}$ The consequences for the interpretation of Aristotle's political theory shall be discussed briefly there. The Politica however is not the only work by Aristotle on politics. Another Aristotelian treatise on politics (On the Constitution of Athens) was lost for a very long time and only found on a papyrus in $1890,{ }^{10}$ whereas there is also a short treatise, the Politikos of which we only know a fragment. We shall leave these works for the present survey undiscussed.

Aristoteles stresses here as elsewhere the link between ethics and politics, but there is also a sometimes neglected link with the Theory of Ideas of Plato. An example for this are the six forms of government which he distinguishes: for the government of one ruler he coined the expressions monarchy and tyranny; government of a small group he calls aristocracy and oligarchy; politeia and democracy is the designation for government in popular assemblies. All these forms still are a mirror of the theory of ideas by Plato: here we find "ideal" forms of government compared with the daily life forms of political organization. ${ }^{11}$ The preferred form of government is for Aristotle in the ideal world aristocracy. He was however fully aware that aristocracies tend to degenerate in daily life in oligarchies, therefore in daily life he preferred democracy. ${ }^{12}$ Quite remarkably all these forms of political organization survive as models until this very day. ${ }^{13}$ Here is one of the main sources:

Aristotle, Politics IV, 2, 1, 1289 a 26-31

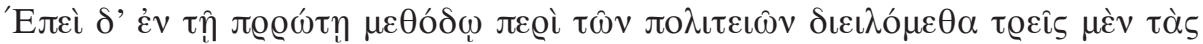

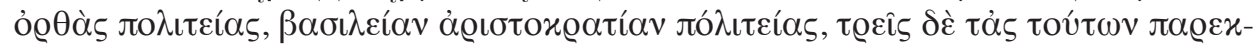

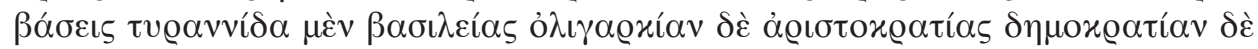

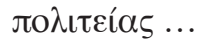

6 FLÜCKIGER, op. cit., p. $168 \mathrm{ff}$.

7 This follows for example from some cross references that are still present in the text of the Politics. For the complicated textual history of the Ethica Nicomacheia see GAUTHIER, R. A. - JOLIF, J. Y. AristoteL'Éthique à Nicomaque. I, 1. Louvain: Publications universitaires, 1970, p. 63ff. For the history of the transmission of the Politics see DÜRING, I. Aristoteles, Darstellung und Interpretation seines Denkens. Heidelberg: C. Winter, 1966, p. 474ff.

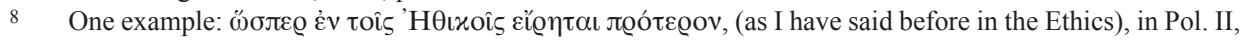
1, 5, 1261a 32; see also Pol. 1295a 38 and infra note 19.

9 It is questionable whether current research has taken this fact into consideration sufficiently.

10 GUTHRIE, W. K. C. A History of Greek Philosophy. VI. Cambridge: Cambridge University Press, 1981, pp. 334-335; DÜRING, op. cit., p. 477.

11 SABINE, G. H. - THORSON, T. L. A History of Political Theory. Hinsdale/Illinois: Dryden Press - Tokyo: Holt-Saunders, 1973, p. $95 \mathrm{ff}$.

12 SABINE - THORSON, op. cit., p. 113ff; cfr. also LANGEMEIJER, G. E. Inleiding tot de Wijsbegeerte van het recht. Zwolle: W.E.J. Tjeenk Willink, 1970, s. 42.

13 SABINE - THORSON, op. cit., p. 105-106. We leave aside the interesting philosophical and methodological problems linked with a long-term "historical" set of typologies in political science. 
"And inasmuch as in our first inquiry about the forms of the constitution we classified the right constitutions as three: kingship, aristocracy and constitutional government, and the deviations ( $\pi \alpha \rho \varepsilon \kappa \beta \alpha \dot{\sigma} \sigma \varepsilon 1 \varsigma)$ from these are three, tyranny from kingship, oligarchy from aristocracy and democracy from constitutional government ..."14

A few lines later Aristotle continues this division of political organization, but follows another train of thought:

Aristotle, Politics IV, 3, 1, 1289 b 26-32

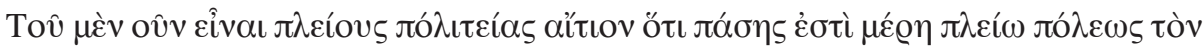

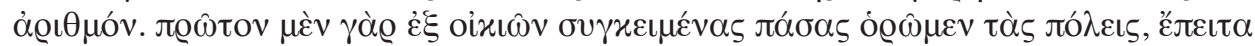

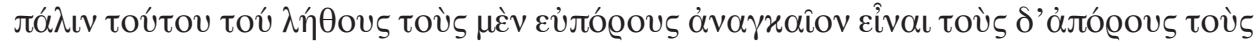

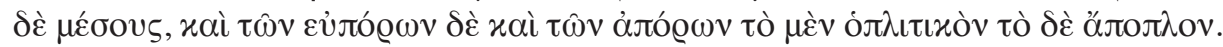

"Now the reason of there being several forms of constitution is that every city has a considerable number of parts. For in the first place we see that all cities are composed of households, and then again that of this multitude some must necessarily be rich and some poor and some between the two, and also of the rich and the poor the former class is heavyarmed and the latter without armour." 15

The construction of human society begins with the word oixí $\alpha$ (house, household) as a starting point. The word oikeiosis is etymologically close to oikia. Hence a part of philosophy which is called the doctrine of oikeiosis of which we find two species: one in Aristotle, one in Stoic philosophy. ${ }^{16}$ The idea is that the intensity of human relations can be imagined as a set of concentric circles with the strongest intimacy for the inner circle.

According to these two quoted fragments Aristotle could indeed be considered as an early (legal) sociologist, an opinion already defended some 120 years ago by the American scholar Charles Ellwood ${ }^{17}$ in the early course of the modern development of this branch of (legal) science.

In the following fragment a kind of proto-sociological approach prevails as well. The well-known Aristotelian Theory of the Mean ${ }^{18}$ ( $\left.\mu \varepsilon \varepsilon \sigma o v / \mu \varepsilon ́ \sigma o \tau \eta \varsigma\right)$ with its origin in physics and ethics (Book II of the Nicomachean Ethics) is also applied in political theory. This follows from:

Aristoteles, Politics IV, 9, 2, 1295a 35-1295 b2

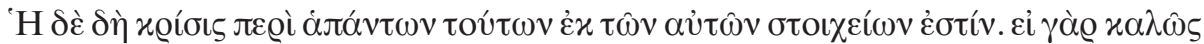

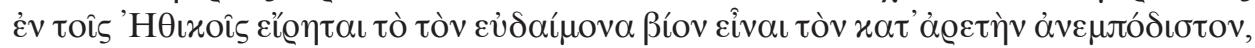

14 ARISTOTLE. Politics. Translated by RACKHAM, H. Cambridge: Harvard University Press, 1932.

15 Ibidem.

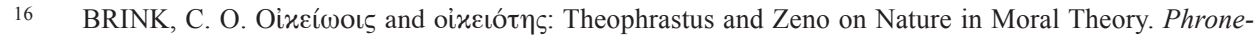

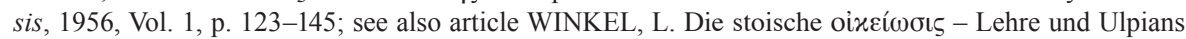
Definition der Gerechtigkeit. Zeitschrift der Savigny Stiftung für Rechtsgeschichte. Rom. Abteilung, 1988, Vol. 105, pp. 669-679.

17 ELLWOOD, CH. Aristotle as a sociologist. Annals of the American Academy of Political Science, 1902, Vol. 19, pp. 227-237.

18 DÜRING, op. cit., p. 448 with further references; HARDIE, W. F. R. Aristotle's Doctrine that Virtue is a Mean. In: BARNES, J. - SCHOFIELD, M. - SORABJI, R. Articles on Aristotle, 2: Ethics and Politics. London: Gerald Duckworth \& Co Ltd, 1977, pp. 33-46 (older slightly different version in: Proceedings of the Aristotelian Society, 1965-6, Vol. 65, pp. 183-205); URMSON, J. O. Aristotle's Doctrine of the Mean. In: OKSENBERG RORTY, A. (ed.). Essays on Aristotle's Ethics. Berkeley et al.: University of California Press, 1980, pp. 157-170. 


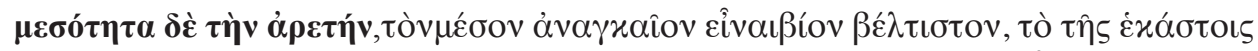

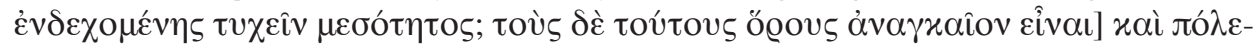

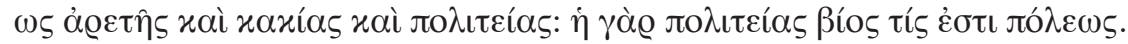

"And indeed the decision in regard to all these questions is based on the same elementary principles. For if it has been rightly said in the Ethics ${ }^{19}$ that the happy life is the life that is lived without impediment in accordance with virtue, and that virtue is a middle course, it necessarily follows that the middle course of life is the best - such a middle course as it is possible for each class of men to attain. And these same criteria must also necessarily apply to the goodness and badness of a state and of a constitution - for a constitution is a certain mode of life of a state." 20

The text continues with a kind of sociological analysis of society and praises people with moderate wealth, not extremely rich and not extremely poor as the cornerstones of the political human society, just in accordance with the Theory of the Mean explained also elsewhere, most clearly in the second book of the Nicomachean Ethics (EN II, $151106 \mathrm{~b}$ $37-1108$ b 6).

Another interesting phenomenon in Aristotle's Politics is a kind of "prefiguration" of the separation of power, expounded in more modern times in a well-known text of Montesquieu, De l'esprit des Lois, XI 6:

«Il y a, dans chaque état, trois sortes de pouvoirs; la puissance législative, la puissance exécutrice des choses qui dépendent du droit des gens, \& la puissance exécutrice de celles qui dépendent du droit civil. Par la première, le prince ou le magistrat fait des loix pour un temps ou pour toujours, \& corrige ou abroge celles qui sont faites. Par la seconde, il fait la paix ou la guerre, envoie ou reçoit des ambassades, établit, la sûreté, prévient les invasions. Par la troisième, il punit les crimes, ou juge les différends des particuliers. On appellera cette dernière la puissance de juger; \& l'autre, simplement la puissance exécutrice de l'état. »"

This text can be linked with Aristotle, as appears in the following text:

Aristoteles, Politics IV 11 (1297 b 35-1298 a 3)

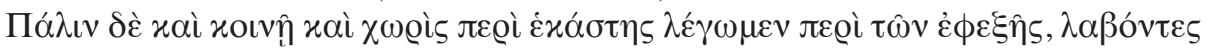

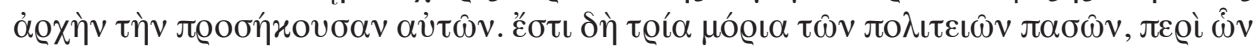

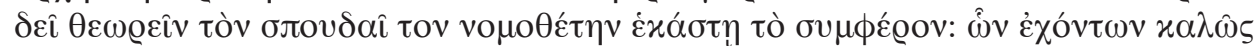

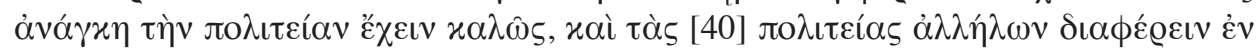

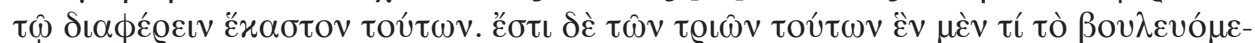

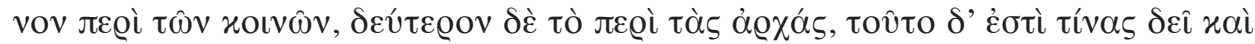

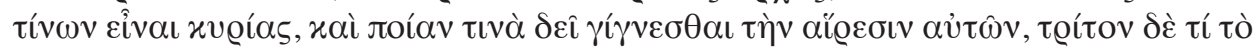

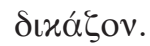

"And again, let us speak about the points that come next, both generally and with reference to each constitution separately, taking their appropriate starting point. All forms of constitution then have three factors in reference to which a good lawgiver has to consider what is expedient for each constitution; and if these factors are well-ordered the constitution must of necessity be well-ordered, and the superiority of one constitution over another necessarily consists in the superiority of each of these factors. Of these three factors one is,

19 We find here another cross reference to the Ethics in the Politics, see supra note 7.

20 ARISTOTLE. op. cit. 
what is to be the body that deliberates about the common interests, second the one connected with the magistracies, that is, what there are to be and what matters they are to control, and what is to be the method of their election, and a third is, what is to be the judiciary."21

The question must be briefly dealt with whether Montesquieu was able to quote Aristotle. ${ }^{22}$ Indeed there are several instances where he does, ${ }^{23}$ and the general information about the availability of Aristotle's writings in the 17th century goes in the same direction, so the answer is positive. This leads to the important question: how did this thought of Aristotle spread generally speaking? Legal humanism which began in the 16th century ended later (17th and 18th century) in criticizing royal absolutism, for example in France. It might be possible to establish a more or less direct link but this is out of the scope of the present survey. It was legal humanism that in the end was the intellectual background of criticism of royal absolutism. One can also ask whether there was any evidence that this text was put earlier in relation with political reality.

The history of the transmission of Aristotle's Politics ${ }^{24}$ is indeed quite different from the history of the textual transmission of the ethical treatises. It seems that Aristotle's Politics were available without a substantial interruption until the beginning of the Christian era ${ }^{25}$ and later on as well, albeit in a Latin translation, whereas especially the transmission of the Nicomachean Ethics is a far more complicated story. It seems that the Nicomachean Ethics were forgotten after Aristotle's death in 322 but only became again available in the first century BC. ${ }^{26}$ Aristotle's Politics and the Nicomachean Ethics were both available throughout the Middle Ages albeit in a Latin translation and during the Renaissance again in the original Greek: ${ }^{27}$ it is a common place that Jean Bodin (1530-1596), the well-known French political philosopher of the Renaissance was thoroughly influenced by Aristotle. ${ }^{28}$

There is a strange coincidence in political history in the year $322 \mathrm{BC}$ : Aristotle and Alexander the Great died in that same year. Political events do reflect also in philosophy! From this moment on we see the rise of Stoic cosmopolitism and Stoic political philosophy. The

21 Ibidem.

22 SABINE - THORSON, op. cit., p. $510 \mathrm{ff}$.

23 See for example De l'Esprit des Loix, IV, 8.; XI, 9 et passim.

24 See SABINE - THORSON, op. cit., p. $513 \mathrm{ff}$; DÜRING, op. cit., p. 474ff (see supra note 5).

25 AALDERS, G. J. D. Theorie der gemischten Verfassung im Altertum. Amsterdam: Adolf M. Hakkert Verlag, 1968, 54ff; SABINE - THORSON, op. cit., pp. 115-117.

26 The current opinion is that the esoteric writings (under which the Nicomachean Ethics) of Aristotle were re(dis)covered in the course of the first century BC, see the important article of CHROUST, A. H. The miraculous disappearance and recovery of the Corpus Aristotelicum. Classica et Mediaevalia, 1962-1963, Vol. XXIII, pp. 50-67, and GUTHRIE, A History of Greek Philosophy, VI, p. 331ff. For the complicated history of the transmission of the ethical treatises of Aristotle see also KENNY, A. The Aristotelian Ethics. Oxford: Clarendon Press, 1978, p. 1ff; a short survey also in WINKEL, L. Error iuris nocet. I. Zutphen: Terra, 1985, pp. 22-24; 68ff.

27 Cfr. DOD, B. - LOHR, CH. Aristotle in the middle ages. In: KRETZMANN, N. et al. (eds.). The Cambridge History of Later Medieval Philosophy. Cambridge: Cambridge University Press, 1982, pp. 45-98. See also DUNBABIN, J. The reception and interpretation of Aristotle's Politics. In: KRETZMANN, N. et al. (eds.). The Cambridge History of Later Medieval Philosophy. Cambridge: Cambridge University Press, 1982, pp. 723-737; GRAFTON, A. The availability of ancient works, s.v. Aristotle. In: SCHMITT, C. B. - SKINNER, Q. et al. (eds.). The Cambridge History of Renaissance Philosophy. Cambridge: Cambridge University Press, 1988, pp. 777-778.

28 SABINE - THORSON, op. cit., p. 374ff. Bodin's main work Les six livres de la République was published in 1576 . 
model of the city state is gradually outdated after the conquests of Alexander the Great and territory became more important. In political theory there is a link of internal public law with emerging forms of international law. City states could only survive when there were alliances with other city states whereas territorial states are less dependent upon each other. Hence a great number of treaties between city state throughout the Mediterranean.

A link between politics and emerging international law can be established through the following, albeit not very clear fragment:

Aristoteles, Politics III,5,10, 1280 a 35-40

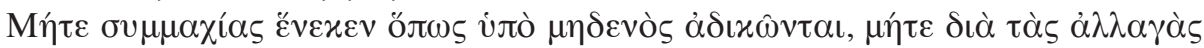

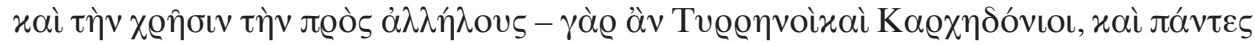

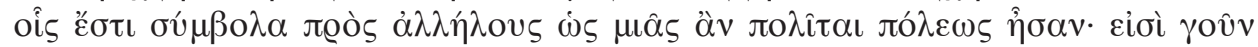

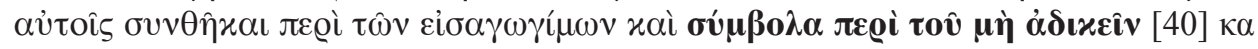

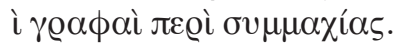

"And if its object is not military alliance for defence against injury by anybody, and it does not exist for the sake of trade/exchange and business relations - for if so, Etruscans and Carthagenians and all the people that have commercial relations with one another would be virtually citizens of a single state; at all events they have agreements about imports and covenants as to abstaining from dishonesty and treaties of alliance for mutual defence." 29

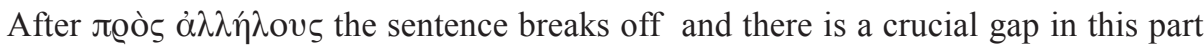
of the text, as far as we can see crucial for understanding the real meaning of Aristotle's political philosophy. "Dishonesty" seems therefore to be a somewhat colourless translation of $\alpha \delta ı x i ́ \alpha$, because it must be kept in mind that in Greek (private) law there is no fundamental distinction between tort law and breach of contract. According to Laqueur

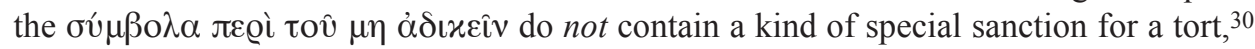
but this kind of treaty aims at the furthering of commercial relations in general. In this framework liability in international commercial relations is established in a treaty, where tortious and contractual liability are not yet distinguished, just as in Athenian (private) law,

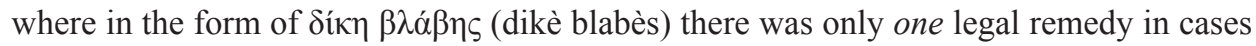
of tort and breach of contract. ${ }^{31}$ The colourless translation of $\dot{\alpha} \delta\llcorner x i ́ \alpha$ seems therefore more or less appropriate.

The influence of Gorgias and his pupil Lycophron is visible in a concrete description of this treaty. Lycophron is quoted a few lines after this reference to the treaty and he is the father of the definition of nomos (vó $\mu \circ \varsigma$ ) given a few lines earlier and formulates, perhaps

29 ARISTOTLE. op. cit.

30 See MORAUX, P. Der Aristotelismus bei den Griechen. I, II, III. Berlin: De Gruyter, 1973 - 1984 -

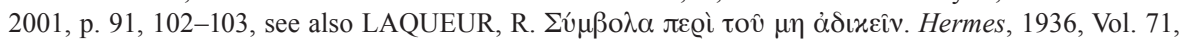
pp. 469-472.

31 See LIPSIUS, J. H. Das attische Recht und Rechtsverfahren. Repr. Hildesheim: Olm s, 1966, p. 652ff, especially p. 653. The opinion according to which the Roman distinction obligatio ex contractu and obligatio ex delicto is of Greek origin is therefore certainly correct, but does NOT have its origin in Greek law, but in Greek philosophy, see my article Alcune osservazioni sulla classificazione delle obbligazioni e sui contratti nominati nel diritto romano. Bullettino dell'Istituto di Diritto Romano. III ${ }^{\mathrm{a}}$ serie, 2000-2001, [pubbl. 2009], Vol. CIII-CIV, pp. 51-66, esp. pp. 55-58. 
for the first time that the "nomos" is a kind of contract between the citizens. ${ }^{32}$ Etruscans and Carthaginians conclude a treaty in the quoted text "as if they were virtually citizens of a single state", a hint to cosmopolitanism. This text also implies emerging "international" arbitration albeit for Aristotle here still hypothetical. This might be a sign for a change in the political landscape in the Hellenistic era after the death of Alexander the Great: we see a development from city states towards a more territorial structure of larger states and a growing tendency to legally protected "international" trade.

We also see this last tendency in Roman history: in Rome $242 \mathrm{BC}$, eighty years after the death of Aristotle and Alexander the Great, and a year before the end of the First Punic War, there is at first sight a curious coincidence. A new magistrate is instituted, the praetor peregrinus who allows certain privileged foreigners (peregrini) to Roman judicial protection and litigation, nearly at the same time in which the First Punic War ended. However, in hindsight the institution of this new praetor is understandable. What Aristotle foresaw with regard to an international community of city states turned out to become the new political reality: the end of the city state as a common political framework. This also changed the philosophical climate in Greece and later on also in Rome. The Stoic doctrine of Chrysippus and Zeno about a truly universal concept of natural law was gradually prevailing. ${ }^{33}$ This is the development from the city state (polis) to universalism and politically speaking: to more "territorial" forms of government. Here is the main well-known text:

Cicero, De re publica III, 22, 33 ( = SVF III, 325)

XXII...Est quidem vera lex recta ratio naturae congruens, diffusa in omnes, constans, sempiterna, quae vocet ad officium iubendo, vetando a fraude deterreat; quae tamen neque probos frustra iubet aut vetat nec improbos iubendo aut vetando movet. Huic legi nec obrogari fas est neque derogari ex hac aliquid licet neque tota abrogari potest, nec vero aut per senatum aut per populum solvi hac lege possumus, neque est quaerendus explanator aut interpres eius alius, nec erit alia lex Romae, alia Athenis, alia nunc, alia posthac, sed et omnes gentes et omni tempore una lex et sempiterna et immutabilis continebit, unusque erit communis quasi magister et imperator omnium deus, ille legis huius inventor, disceptator, lator; cui qui non parebit, ipse se fugiet ac naturam hominis aspernatus hoc ipso luet maximas poenas, etiamsi cetera supplicia, quae putantur, effugerit... (= Lactantius, Institutiones Divinae, VI, 8, 6-9)

"... True law is right reason in agreement with nature; it is of universal application, unchanging and everlasting; it summons to the duty by its commands, and averts from wrongdoing by its prohibitions. And it does not lay its commands or prohibitions upon good men in vain, though neither have any effect on the wicked. It is a sin to try to alter this law, nor is it allowed to attempt to repeal any part of it, and it is impossible to abolish it entirely. We cannot be freed from its obligations by senate or people, and we need not look outside ourselves for an expounder or interpreter of it. And there will not be different laws at Rome and at Athens, or different laws now and in the future, but one eternal and unchangeable law will be valid for all nations and all times, and there will be one master and ruler, that is God, over us all, for he is the author of this law, its promulgator, and its

\footnotetext{
32 A very early instance of the idea of societal (social) contract revived in the 18th century by Jean Jacques Rousseau, see SABINE - THORSON, op. cit., p. 529 ff.

33 FLÜCKIGER, op. cit., pp. 225-226.
} 
enforcing judge. Whoever is disobedient is fleeing from himself and denying his human nature, and by reason of this very fact he will suffer the worst penalties..." 34

One can easily see the importance of this text for the transmission of philosophical ideas of Antiquity, but - strange enough - there is no direct transmission of this text in a purely Ciceronian manuscript, it is indeed embedded in the text of the Institutiones of the Christian author Lactantius. (CE 250-325). Hans von Arnim (1859-1931) took this text as a typical testimony of Stoicism in his famous collection, the Stoicorum veterum fragmenta. ${ }^{35}$ This text does not prove, however, that cosmopolitism was already prevailing in $242 \mathrm{BC}$, but it can be considered as its announcement for the future. This text is also remarkable for the direct comparison made between Athens and Rome in Cic. De Rep III, 22, 33, although as has been said, the context and the argumentation of this text are not totally clear. ${ }^{36}$

The rising idea of Cosmopolitanism goes together with gradual changes in the political structure of Rome. Important in this respect on the institutional level was the introduction of the praetor peregrinus in Rome in $242 \mathrm{BC}$. The introduction of this new magistrature did not only have legal, but also economic and political reasons. This year $242 \mathrm{BC}$ marked more or less the end of the First Punic war between Rome and Carthago - in fact it ended one year later - and Rome turned out to be victorious. Hence the introduction of a legal institution in the form of the creation of a new magistrate, the praetor peregrinus to further the external economic relations and to provide those relations with legal protection. From now on Rome was gradually succeeding Carthago as the main political and economic power in the Western Mediterranean. ${ }^{37}$ An example for the usual commercial treaties were possibly the symbola in Greece, once a current Mediterranean legal practice in the eastern part which was adopted by Rome and from now on refined. ${ }^{38}$ This resulted in a network of treaties between Rome and other city states in which the inhabitants of foreign city states acquired the status of peregrinus in Rome and in this way they obtained protection of their commercial relations with Rome. In the developed Roman Empire we find a variety of commercial treaties and a hierarchy of "foreign" city states: there are civitates foederatae, there were civitates immunae atque liberae, civitates sine suffragio, civitates stipendiariae and coloniae. ${ }^{39}$

\section{Conclusions}

Universalist forms of philosophy have had impact on emerging international law and political theory, not only in the time of Greek city states, but also in the epoch in which Rome was gradually dominating the Mediterranean world. However, there never was a prevailing

34 Cicero XVI: De Re Publica. De Legibus. Translated by KEYES, C. W. Cambridge, MA: Harvard University Press, 1988.

35 VON ARNIM, H. Stoicorum veterum fragmenta. I-IV. Repr. Stuttgart: Teubner, 1979.

36 See VILLEY, M. Rückkehr zur Rechtsphilosophie. In: BÜCHNER, K. (ed.). Das Neue Cicerobild. Darmstadt: WBG, 1971, p. $274 \mathrm{ff}$.

37 ZIEGLER, K. H. Völkerrechtsgeschichte. München: C. H. Beck, 2007, p. 38.

38 GRUEN, E. S. The Hellenistic World and the Coming of Rome. Berkeley - Los Angeles - London: University of California Press, 1984, p. 72, 105, 107.

39 See BENGTSON, H. Staatsverträge des Altertums. I-IV. Repr. Berlin - Munich: C. H. Beck, 1962. See also Cicero In Verrem for the situation on Sicily where a wide variety of dependent and independent city states were present each with their own peculiar legal and political position. 
ideology or philosophy in Antiquity, but within the framework of Roman legal texts there is a colourful variety of universal and particular legal and philosophical concepts.

Stoic philosophy, however, was a great help in establishing the Roman hegemony in the Mediterranean world by underpinning the shared values of commercial interests and natural law. Many texts on the concept of ius gentium for example can be understood within this framework.

A further but by no means very spectacular conclusion of this short paper could be that the history of textual transmission of philosophical texts is often a decisive explanation for changes in prevailing philosophical and legal thought. ${ }^{40,41}$

40 Further reading: HIRZEL, R. Agraphos nomos. Leipzig: Teubner, 1903. JONES, J. W. The Law and Legal Theory of the Greeks. Oxford: Clarendon Press, 1956. Repr. Aalen: Scientia Verlag, 1977. MENZEL, A. Kallikles, Eine Studie zur Geschichte der Lehre vom Rechte des Stärkeren. Leipzig: Franz Deuticke, 1922. MOREAU, P. Symbola: Les étrangers et la justice dans les cités grecques. Nancy: Université de Nancy II, 1972. POHLENZ, M. Die Stoa, Geschichte einer geistigen Bewegung. I-II. Göttingen: Vandenhoeck \& Ruprecht, 1978-1980. DE ROMILLY, J. La douceur dans la pensée grecque. Paris: Les Belles Lettres, 1979. DE ROMILLY, J. La loi dans la pensée grecque. Paris : Les Belles Lettres, 1971. WINKEL, L. Some thoughts on the formulae ficticiae of citizenship in Gaius, 4,37: a form of reception? In: BARROWS, A. JOHNSTON, D. - ZIMMERMANN, R. (eds.). Judge and Jurist - Studies in Memory of Lord Rodger of Earlsferry. Oxford: Oxford University Press, 2013, pp. 299-308.

41 Elaborated text of a short presentation held on November 21, 2019 in Prague at the occasion of the meeting of the 'Giuria del Premio Boulvert'. 